\title{
Photocatalytic disinfection of marine bacteria using fluorescent light
}

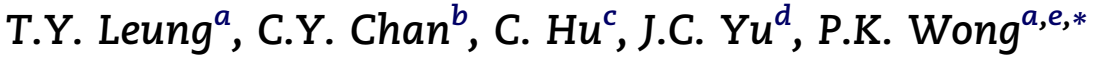 \\ ${ }^{a}$ Department of Biology, The Chinese University of Hong Kong, Shatin, N. T., Hong Kong SAR, China \\ bepartment of Microbiology, The Chinese University of Hong Kong, Shatin, N. T., Hong Kong SAR, China \\ ${ }^{\mathrm{c}}$ Research Center for Eco-Environmental Sciences, Chinese Academy of Sciences, Beijing 100085, China \\ ${ }^{\mathrm{d}}$ Department of Chemistry, The Chinese University of Hong Kong, Shatin, N. T., Hong Kong SAR, China \\ ${ }^{e}$ Environmental Science Programme, The Chinese University of Hong Kong, Shatin, N. T., Hong Kong SAR, China
}

\section{A R T I C L E I N F O}

Article history:

Received 20 June 2008

Received in revised form

28 August 2008

Accepted 29 August 2008

Published online 20 September 2008

Keywords:

Photocatalytic oxidation

Bacterial inactivation

Fluorescent light

Marine bacteria

\begin{abstract}
A B S T R A C T
Photocatalytic oxidation (PCO) using fluorescent light was used to disinfect two marine bacteria: Alteromonas alvinellae and Photobacterium phosphoreum. Results showed that P. phosphoreum exhibited a lower susceptibility towards PCO than A. alvinellae, which was related to their fatty acid profiles and levels of superoxide dismutase (SOD) and catalase (CAT). Results also revealed that CAT and SOD levels would be triggered by PCO reaction. In addition, PCO disinfection efficiency could be enhanced by acidic $\mathrm{pH}$ levels and increased temperatures, while different growth phases demonstrated diverse effects to the studied bacteria, probably due to their morphological difference or change in physiological state. Lastly intracellular leakage of potassium ion $\left(\mathrm{K}^{+}\right)$, in line with the loss of cell viability, was observed during PCO. Mineralization of bacteria by PCO was monitored by total organic carbon analysis. From the regrowth study, the tested strains failed to reactivate within $96 \mathrm{~h}$ after PCO treatment, indicating PCO caused irreversible bacterial inactivation.
\end{abstract}

(c) 2008 Elsevier Ltd. All rights reserved.

\section{Introduction}

The lack of improved water supply, sanitation and hygiene has been attributed to the water crisis that is currently being experienced by human beings in this century. Approximately $20 \%$ of the global population is in need of access to clean water supplies and $40 \%$ requires resources for sanitation, and, as a consequence, two million deaths occur worldwide every year (World Health Organization, 2004). Thus, the provision of safe and clean water supplies is a key issue to protecting human health and the environment.

Photocatalytic oxidation (PCO) is an advanced oxidation process (AOP) utilizing a semiconducting photocatalyst such as titanium dioxide $\left(\mathrm{TiO}_{2}\right)$ and appropriate light sources such as ultraviolet (UV) irradiation $(\lambda \leq 380 \mathrm{~nm})$ to generate charge carriers $\mathrm{e}^{-}$and $\mathrm{h}^{+}$) (Saito et al., 1992; Maness et al., 1999). These charge carriers react with species that are adsorbed on their surface to generate a highly reactive hydroxyl radical $(\cdot \mathrm{OH})$. Due to its highly oxidative and reactive nature, $\cdot \mathrm{OH}$ oxidizes the cell membrane and damages the microbial structure (Maness et al., 1999).

Bacterial sensitivity towards oxidative attack varies among species. As proposed by Dunlop et al. (2002), the cell membrane acts as the primary site of oxidative attack. Moreover, the relationship between the thickness and complexity of cell wall, as well as the cell membrane and

* Corresponding author. Department of Biology, The Chinese University of Hong Kong, Shatin, N. T., Hong Kong SAR, China. Tel.: +852 2609 6383; fax: +852 26035767.

E-mail address: pkwong@cuhk.edu.hk (P.K. Wong).

0043-1354/\$ - see front matter @ 2008 Elsevier Ltd. All rights reserved.

doi:10.1016/j.watres.2008.08.031 
extent of inactivation, was previously reported (Matsunaga et al., 1988). The article indicated that the fatty acid composition of cellular lipids, which are found in the outer and cytoplasmic membrane, would amount to different bacterial sensitivity towards oxidative damage. Also, almost all aerobic organisms are equipped with intricate defense and repair mechanisms against oxidative stress from the environment in addition to the natural aerobic metabolism inside bacteria (Farr and Kogoma, 1991). Examples include enzymes such as superoxide dismutase (SOD) and catalase (CAT). It is assumed that bacteria with these defense mechanisms against oxidative stress will be more difficult to be inactivated by PCO.

Many research groups have focused on $\mathrm{UV} / \mathrm{TiO}_{2}$ photocatalysis on bacteria and the effects of operational parameters such as light intensity or chemical composition of water. However, only a few attempts have been made to study the intrinsic factors. These factors include antioxidative enzymes, the fatty acid profile inside bacteria and the disinfection towards bacteria. In addition, there is a rising demand for the enhanced water quality in mariculture areas such as aquariums, seafood tanks, indoor fishing ponds and shrimp farms.

In this project, $\mathrm{PCO}$ reactions were performed using $\mathrm{TiO}_{2}$ coupled with a fluorescent lamp, which is commonly used for household lighting. Emitting trace amounts of UV-A, UV-B and UV-C was sufficient for bacterial inactivation (Pal et al., 2007), which suggests that the utilization of fluorescent light does not only apply practically in an indoor environment, but it can also provide a cheaper, safer, more easily available and environmentally friendly option for bacterial disinfection by means of UV irradiation.

In the present study, the disinfection efficiency of PCO using $\mathrm{TiO}_{2}$ and fluorescent light towards two marine bacteria was examined. Then the roles of the two antioxidative enzymes (i.e. SOD and CAT) in preventing oxidative attack from PCO were studied. In addition, the fatty acid profile of the selected bacteria was investigated to find its correlation with bacterial sensitivity towards PCO attack. Finally, the leakage of $\mathrm{K}^{+}$and total organic carbon (TOC) analyses were also performed to facilitate the understanding on the inactivation mechanism of PCO reactions towards bacterial disinfection.

\section{Material and methods}

\subsection{Preparation of reaction mixture}

Titanium dioxide, $\mathrm{TiO}_{2}$ (P25) purchased from Degussa Corporation (Frankfurt, Germany), was used as the semiconductor photocatalyst for all experiments. It was in its crystalline form (70\% anatase and 30\% rutile) and had a BET surface area of $50 \mathrm{~m}^{2} / \mathrm{g} .10,000 \mathrm{mg} / \mathrm{L}$ of $\mathrm{TiO}_{2}$ stock solution was prepared by suspending $10 \mathrm{~g}$ of $\mathrm{TiO}_{2}$ powder in $1 \mathrm{~L}$ of ultrapure water. The solution was then homogenized by sonication at $35 \mathrm{kHz}$ for $20 \mathrm{~min}$ and kept in the dark at room temperature. The reaction mixture $\left(100 \mathrm{mg} / \mathrm{L} \mathrm{TiO}_{2}\right)$ was made by adding $0.5 \mathrm{~mL}$ of $\mathrm{TiO}_{2}$ stock solution to a $3.0 \% \mathrm{NaCl}$ solution to give a total volume of $45 \mathrm{~mL}$. All reaction mixtures were sterilized by autoclaving at $121^{\circ} \mathrm{C}$ for $20 \mathrm{~min}$ and kept in the dark before use.

\subsection{Preparation of bacterial culture}

The two marine bacteria strains Alteromonas alvinellae and Photobacterium phosphoreum were obtained from the HKUST marine bacterial stock collection. They were cultured in a $10 \%$ nutrient broth (NB) (Biolife, Milano, Italy) solution at $30^{\circ} \mathrm{C}$ and agitated at $200 \mathrm{rpm}$ for $16 \mathrm{~h}$. The cultures were then washed twice with a $3.0 \% \mathrm{NaCl}$ solution by centrifugation at $13,000 \mathrm{rpm}$ for $5 \mathrm{~min}$ at $25^{\circ} \mathrm{C}$, and the cell pellet was resuspended in saline solution. Finally, the cell concentration was adjusted so that the final cell density in the reaction mixture reached $3 \times 10^{7} \mathrm{cfu} / \mathrm{mL}$.

\subsection{Photocatalytic reaction}

All the reaction was carried out in a PCO reactor (Plate 1). The reactor could hold 6 lamps and the intensity of visible light and UV on the surface of the reactor flask emitted from UV-A lamps ( $15 \mathrm{~W}$, maximum emission at $365 \mathrm{~nm}$, Cole-Parmer, USA) and fluorescent lamps (15 W, VELOX ${ }^{\circledR}$, Thailand) were measured by a light meter (LI-COR $\left.{ }^{\circledR}, \mathrm{USA}\right)$ and an UVX digital radiometer (UVP $\left.{ }^{\circledR}, \mathrm{USA}\right)$, respectively. Each UV-A lamp emitted visible light, $0.676 \mathrm{~mW} / \mathrm{cm}^{2}$ : UV-A $=0.334 \mathrm{~mW} /$ $\mathrm{cm}^{2}$; UV-B, $0.158 \mathrm{~mW} / \mathrm{cm}^{2}$ and UV-C $=0.041 \mathrm{~mW} / \mathrm{cm}^{2}$. Each fluorescent lamp emitted visible light, $5.295 \mathrm{~mW} / \mathrm{cm}^{2}$; UV-A,

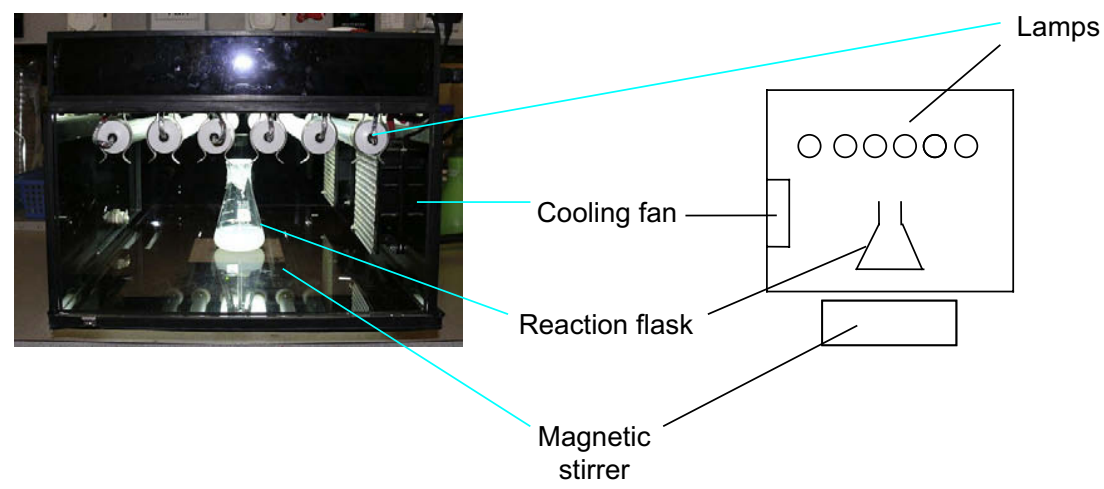

Plate 1 - A photo and a drawing of the PCO reactor. 
$0.015 \mathrm{~mW} / \mathrm{cm}^{2}$ and UV-B $=0.0002 \mathrm{~mW} / \mathrm{cm}^{2}$. No UV-C emission from the fluorescent lamps was detectable. Five milliliters of washed cell culture was added to $45 \mathrm{~mL}$ of a sterilized reaction mixture containing $100 \mathrm{mg} / \mathrm{L}$ of $\mathrm{TiO}_{2}$. The mixture was placed under UV-A or fluorescent lamps, which were mounted inside of the reactor. To reach adsorption/desorption equilibrium, the reaction mixture was stirred in the dark for $30 \mathrm{~min}$ and continuously stirred during the PCO process. The light intensity for UV-A irradiation and fluorescent light were fixed at $0.334 \mathrm{~mW} / \mathrm{cm}^{2}$ and $5.295 \mathrm{~mW} /$ $\mathrm{cm}^{2}$, respectively. At a fixed time interval, an aliquot of the sample was taken and serially diluted with a 3.0\% saline solution. $0.1 \mathrm{~mL}$ of the diluted sample was then immediately spread on nutrient agar plates and incubated at $30^{\circ} \mathrm{C}$ for $24 \mathrm{~h}$. The colonies were then counted and expressed as $\mathrm{cfu} / \mathrm{mL}$ to determine the bacterial population after the PCO process. Three control experiments were carried out by (i) applying UV-A or fluorescent light without the addition of photocatalyst (light control); (ii) applying the photocatalyst alone in the dark (dark control) and (iii) without applying light or photocatalyst (negative control). Each set of experiments was performed three times.

To determine the effect of $\mathrm{pH}$, the $\mathrm{pH}$ level was monitored by adjusting the initial $\mathrm{pH}$ with the addition of a few drops of $1 \mathrm{M}$ $\mathrm{HCl}$ and $1 \mathrm{M} \mathrm{NaOH}$ to the reaction mixture. For this study, the $\mathrm{pH}$ levels that were tested included $\mathrm{pH}$ of 4.0, 5.0, 5.8 and 8.0. The unadjusted $\mathrm{pH}$ reading of the reaction mixture was around 5.8.

\subsection{Measurement of bacterial superoxide dismutase and catalase level}

Superoxide dismutase (SOD) and catalase (CAT) determination experiments were carried out using SOD assay and fluorescent catalase detection kits, respectively (Cell Technology, Mountain View, USA), by following the protocol in the instruction manual (Cell Technology, 2006). The detection principle is based on the formation of yellow WST-1 formazan dye, which is assayed in a spectrophotometer at $450 \mathrm{~nm}$, upon the reduction of the superoxide anion $\left(\bullet_{2}^{-}\right)$ produced from the xanthine oxidase. SOD activity was measured by calculating the inhibition percentage of the following equation:

SOD activity (inhibition rate, \%)

$$
=\frac{\left[\left(A_{\text {control 1 }}-A_{\text {control 3 }}\right)-\left(A_{\text {sample }}-A_{\text {control 2 }}\right)\right]}{\left(A_{\text {control 1 }}-A_{\text {control 3 }}\right)} \times 100 \%
$$

where Control 1 represents the highest signal (without SOD but contains xanthine oxidase); Control 2 represents the net signal from the colored sample; Control 3 represents the lowest signal (without SOD and xanthine oxidase).

The detection of catalase is based on the formation of pink fluorescent resorufin, which is measured during excitation at $570 \mathrm{~nm}$ and emission at $585 \mathrm{~nm}$ by the fluorescent spectrometer. With higher levels of CAT, less of the remaining $\mathrm{H}_{2} \mathrm{O}_{2}$ will react with the non-fluorescent detection reagent and peroxidase, resulting in a lower production of fluorescence reading. CAT activity was measured by the change in fluorescence, which was calculated by subtracting the control (without SOD but contains $\mathrm{H}_{2} \mathrm{O}_{2}$ ) from sample fluorescence. Both SOD and CAT levels are expressed as unit/mL.

\subsection{Fatty acid profile}

Fatty acid (FA) profiles in the selected bacteria were analyzed by gas chromatography using an Agilent HP 6890 Series II gas chromatograph (Hewlett Packard, Palo Alto, USA) that was coupled with an HP 7863 autosampler and a flame ionization detector (FID). Sherlock Microbial Identification System Version 4.5 software was used to identify the relative amounts of fatty acid in the bacteria that were studied. In addition, the fatty acid profile analysis was performed according to the procedure used by Cheng et al. (2007). Briefly, harvested cell pellets were saponified to liberate the fatty acid from the cell. 1:1 hexane/methyl tert-butyl ether was used as the methylating agent to extract fatty acid methyl esters (FAMEs), which was followed by a base wash with $\mathrm{NaOH}$. The organic phase was then removed for GC analysis. FAs were identified by comparing their retention times with Calibration Standard 1 No. 1200-A (Microbial ID, Newark, USA) and with the assistance from a database in the "TSBA40 Library" that was provided by Microbial ID, Inc. Data on the retention time, response and percentage of identified FAs were studied to compare the fatty acid composition among the bacteria.

\subsection{Total organic carbon analysis}

Total organic carbon (TOC) analysis of P. phosphoreum was conducted by adopting the processed used by Cheng et al. (2007) and outlined in the Instruction Manual (Shimadzu Corporation, 2001). In short, two $12 \mathrm{~mL}$ samples from the reaction mixture were taken at each fixed time interval and centrifuged at $13,500 \mathrm{rpm}$ for $10 \mathrm{~min}$. For the solid phase analysis, a total organic carbon (TOC) analyzer TOC- $\mathrm{V}_{\mathrm{CSH} / \mathrm{CSN}}$ with a solid sample measurement module (SSM-5000A, Shimadzu Corporation, Kyoto, Japan) was used. One of the dried cell pellets was combusted in a $900^{\circ} \mathrm{C}$ furnace for the total carbon (TC) measurement, while another cell pellet was allowed to react with $0.4 \mathrm{~mL}$ of $85 \%$ phosphoric acid at $200{ }^{\circ} \mathrm{C}$ to determine the inorganic carbon (IC) content. For the aqueousphase analysis, a $12 \mathrm{~mL}$ sample of supernatant was placed into pre-cleaned sample vials for TOC and IC determination using the autosampler ASI-V that was connected to the TOC analyzer TOC- $\mathrm{V}_{\mathrm{CSH} / \mathrm{CSN}}$ (Shimadzu Corporation, Kyoto, Japan). The TOC value is the difference between TC and IC and the TOC in solid sample is the solid organic carbon (SOC) while TOC in aqueous sample is dissolved organic carbon (DOC).

\subsection{Measurement of the leakage of potassium ion}

To determine the change of potassium ion levels in the selected bacteria during PCO process, at $1 \mathrm{~h}$ intervals, $1.5 \mathrm{~mL}$ of the illuminated bacterial suspension was centrifuged at 13,000 rpm for $10 \mathrm{~min}$. The supernatant was then withdrawn for atomic absorption spectrophotometry analysis on the Z-2300 Polarized Zeeman atomic absorption spectrophotometer (Hitachi High-Technologies, Tokyo, Japan).

\subsection{Bacterial regrowth ability test}

To investigate the ability of bacteria to undergo repair after photocatalytic disinfection, once PCO treatment was performed, 
an entire flask of reaction mixture was aseptically removed from the photocatalytic reactor and kept in dark at $30^{\circ} \mathrm{C}$ with a $200 \mathrm{rpm}$ agitation to allow bacterial repair. After $10 \mathrm{~min}$ and at every $12 \mathrm{~h}$ dark incubation (until recovery time reaching $96 \mathrm{~h}$ ), $500 \mu \mathrm{L}$ aliquot samples were collected and directly plated onto the NA plates and incubated at $30^{\circ} \mathrm{C}$ for $24 \mathrm{~h}$. To ensure detection of any recovered cells, $100 \mu \mathrm{L}$ of disinfected samples were transferred to a solution of $5 \mathrm{~mL}$ of $10 \% \mathrm{NB}$ in the same time intervals as previously mentioned, and incubated at $30^{\circ} \mathrm{C}$ for $24 \mathrm{~h}$. To confirm any occurrence of regrowth after PCO disinfection, $500 \mu \mathrm{L}$ aliquot samples were again plated onto NA plates and incubated at $30^{\circ} \mathrm{C}$ for $24 \mathrm{~h}$. Control experiments were performed by (i) adding $100 \mu \mathrm{L}$ of sterilized ultrapure water and (ii) adding $100 \mu \mathrm{L}$ of untreated sample (dark control) to NB medium.

\section{Results}

\subsection{Control experiments and PCO treatment}

Before investigating the ability of PCO to disinfect the two bacterial species that were tested, control experiments were carried out. Results showed that the bacterial population remained constant in $180 \mathrm{~min}$ under three sets of control experiments (dark, negative and light control). This indicated that the two marine bacteria were resistant to the UV-A and fluorescent light, under the light intensity used in this project. Moreover, it revealed that light irradiation, saline solution and the reaction mixture did not affect the survival of these two bacterial species.

\subsubsection{Comparison of the PCO efficiency using UV-A and} fluorescent lamps

Under the conditions of $100 \mathrm{mg} / \mathrm{L}$ of $\mathrm{TiO}_{2}, 0.334 \mathrm{~mW} / \mathrm{cm}^{2}$ of UV-A irradiation and a $200 \mathrm{rpm}$ agitation rate, complete inactivation (7-log) was achieved in 30 min of PCO reaction for A. alvinellae, while 4.5-log inactivation was achieved in $60 \mathrm{~min}$ for P. phosphoreum (Fig. 1(a)). This indicated that the tested strains were susceptible to UV-driven PCO disinfection, with A. alvinellae being inactivated at a much faster rate than P. phosphoreum under the same experimental conditions.

To investigate the feasibility of an indoor lighting alternative, PCO disinfection was coupled with fluorescent light (Fig. 1(b)). Except for the light source, experimental conditions were identical to the previous section. It was observed that with the use of a fluorescent lamp, the inactivation process was prolonged. Complete inactivation (7-log) was achieved in 120 min of PCO reaction for A. alvinellae, while 4log inactivation was achieved for P. phosphoreum during $180 \mathrm{~min}$ of the PCO process. Results confirmed that by extending the irradiation time, the two marine species were susceptible to fluorescent light-driven PCO disinfection, in which A. alvinellae showed a higher sensitivity towards PCO than P. phosphoreum.

\subsubsection{Effect of initial $p H$, temperature and growth phases} on the PCO disinfection efficiency

Fig. 2(a)-(d) illustrates the effect of initial pH on PCO disinfection efficiency of A. alvinellae and P. phosphoreum. It was found that at a $\mathrm{pH}$ of 4.0, after a 30 min dark period,
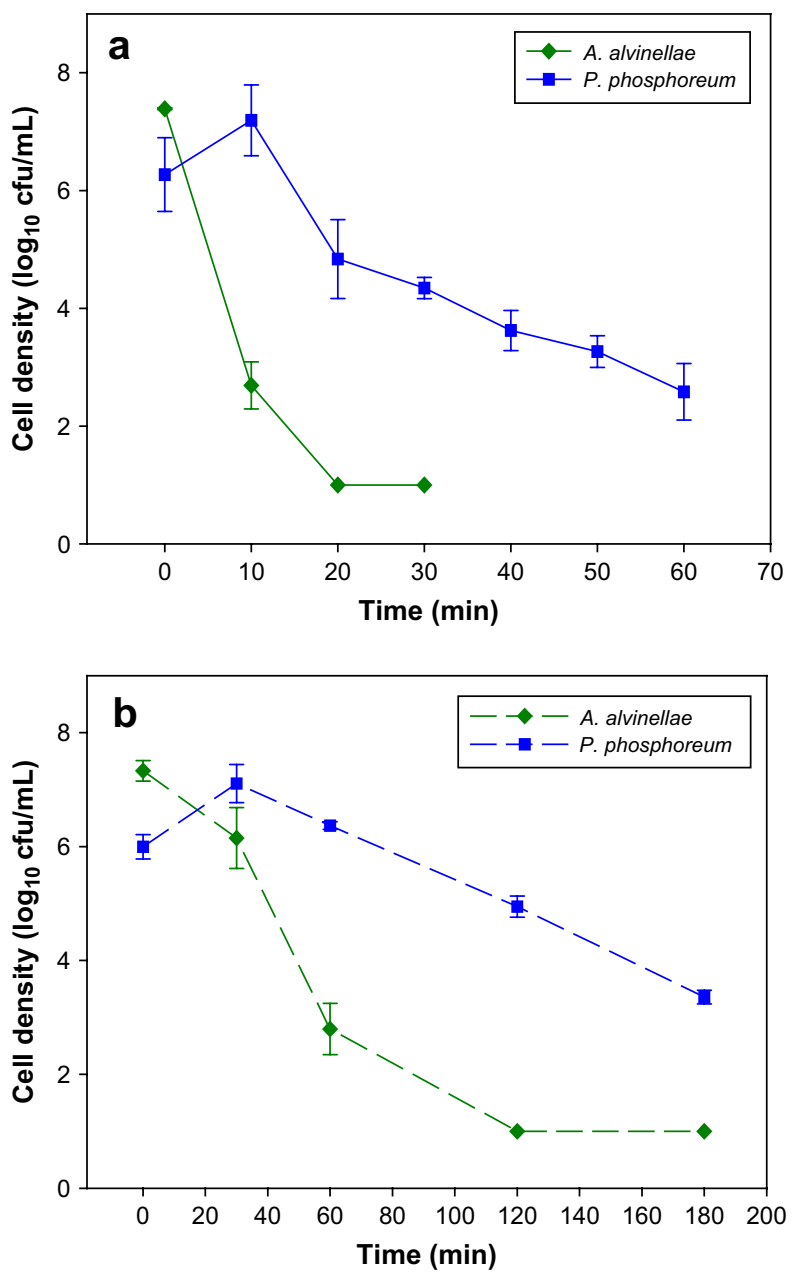

Fig. 1 - Disinfection efficiency of A. alvinellae and P. phosphoreum by PCO using (a) UV-A irradiation (UV intensity $=0.334 \mathrm{~mW} / \mathrm{cm}^{2}$ ) and (b) fluorescent lamp irradiation (visible light intensity $=5.295 \mathrm{~mW} / \mathrm{cm}^{2}$ ). Experimental conditions: $\mathrm{TiO}_{2}$ concentration $=100 \mathrm{mg} / \mathrm{L}$, reaction volume $=50 \mathrm{~mL}$, agitation rate $=200 \mathrm{rpm}$, initial cell density $=3 \times 10^{7} \mathrm{cfu} / \mathrm{mL}$. Each data point and error bar represents the mean and the standard deviations, respectively, of independent triplicates.

complete inactivation (7.5-log) was observed for A. alvinellae and $P$. phosphoreum when they were simply placed in a saline solution, which indicated that the marine bacteria were more sensitive to extremely acidic environments. As a result, initial $\mathrm{pH}$ levels of 5.0, 5.8 and 8.0 were used to compare the inactivation efficiency of PCO. It was noted that A. alvinellae showed no significant effect of $\mathrm{pH}$ on the inactivation efficiency. However, P. phosphoreum showed a gradual enhancement from 1.5-log to 4.5-log inactivation when the $\mathrm{pH}$ level decreased from 8 to 5 during the $180 \mathrm{~min}$ PCO process.

Regarding the effect of reaction temperature on PCO disinfection, graphs showing the disinfection efficiency at different temperatures $\left(15,22,28\right.$ and $\left.37^{\circ} \mathrm{C}\right)$, at time $=$ $120 \mathrm{~min}$, were plotted (Fig. 3). Results indicated that increasing the temperature enhanced the rate of photocatalytic 


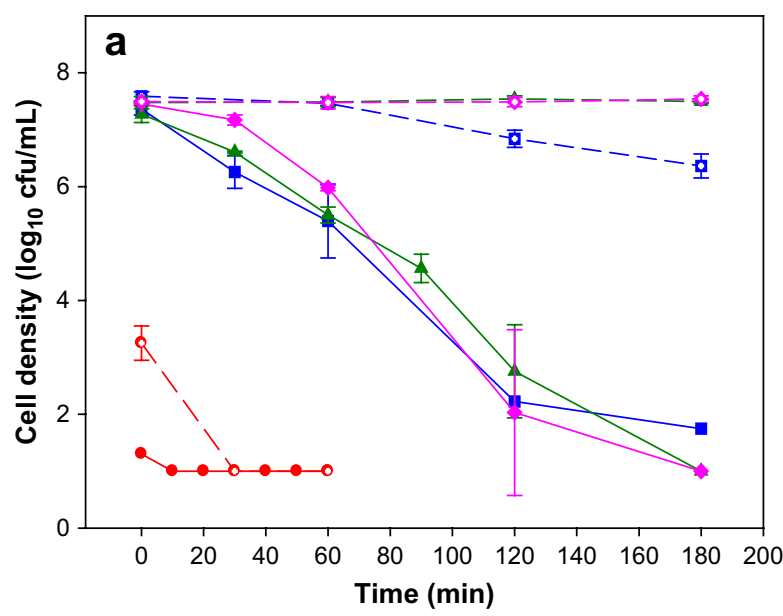

$\longrightarrow$ Net PCO effect at pH $4.0 \pm 0.2-0-$ Negative control at pH $4.0 \pm 0.2$ $\longrightarrow$ Net PCO effect at pH $5.0 \pm 0.2-\square-$ Negative control at $\mathrm{pH} 5.0 \pm 0.2$ at $\mathrm{pH} 8.0+0 . \pm 0.2$

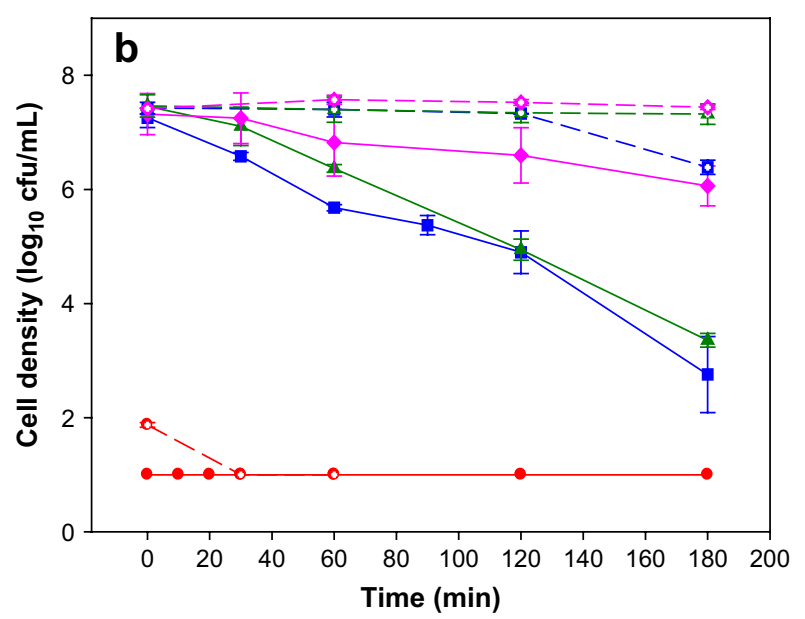

- Net PCO effect at pH $4.0 \pm 0.2-0-$ Negative control at pH $4.0 \pm 0.2$ Net PCO effect at pH 5.0 $\pm 0.2--\mathrm{a}-$ Negative control at pH $5.0 \pm 0.2$ Net PCO effect at pH $5.8 \mp 0.2-\Delta-$ Negative control at pH $5.8 \mp 0 .+0.2$ Net PCO effect at pH 8.0 $\pm 0.2-\diamond-$ Negative control at pH $8.0+0 . \pm 0.2$

Fig. 2 - PCO disinfection of (a) A. alvinellae and (b) P. phosphoreum at different initial pH levels. Experimental conditions: $\mathrm{TiO}_{2}$ concentration $=100 \mathrm{mg} / \mathrm{L}$, light source (intensity) = fluorescent lamp (visible light intensity $=5.295 \mathrm{~mW} / \mathrm{cm}^{2}$ ), reaction volume $=50 \mathrm{~mL}$, agitation rate $=200 \mathrm{rpm}$, initial cell density $=3 \times 10^{7} \mathrm{cfu} /$ $\mathrm{mL}$. Each data point and error bar represents the mean and the standard deviations, respectively, of independent triplicates.

disinfection among the two bacteria. Both bacteria showed an increase in inactivation rate from 2- to 4-log when the reaction temperature was increased from 15 to $37^{\circ} \mathrm{C}$.

Finally, to investigate the effect of growth phases on PCO treatment, mid-log, late-log and stationary phased cells were incorporated into the PCO study (Table 1). Bacteria of different growth stages illustrated diverse survival response under oxidative stress conditions. No significant difference was found in the ease of inactivation for P. phosphoreum under the three growth stages, whereas A. alvinellae expressed no

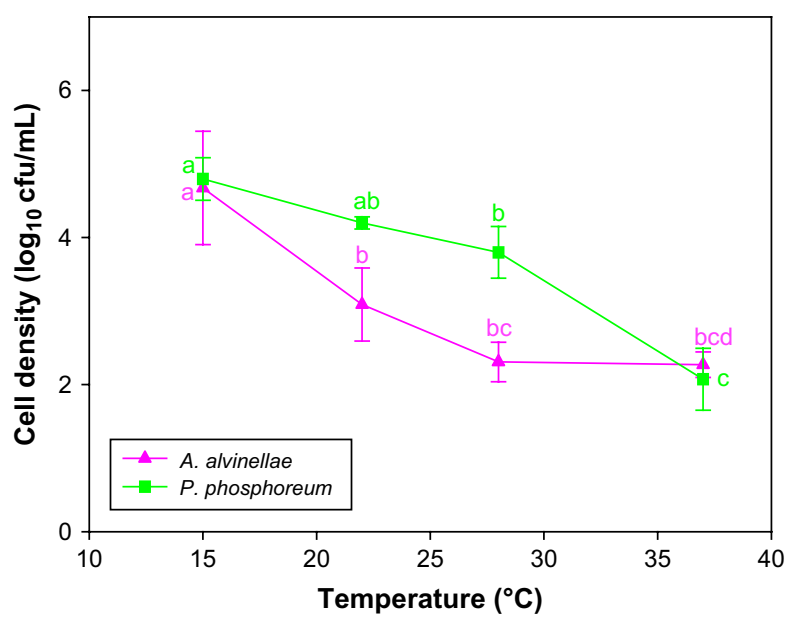

Fig. 3 - PCO disinfection of A. alvinellae and P. phosphoreum at different reaction temperatures during a $120 \mathrm{~min}$ irradiation period. Experimental conditions: $\mathrm{TiO}_{2}$ concentration $=100 \mathrm{mg} / \mathrm{L}$, light source (intensity) = fluorescent lamp (visible light intensity $=5.295 \mathrm{~mW} / \mathrm{cm}^{2}$ ), reaction volume $=50 \mathrm{~mL}$, agitation rate $=200 \mathrm{rpm}$, initial cell density $=3 \times 10^{7} \mathrm{cfu} /$ $\mathrm{mL}$. Each data point and error bar represents the mean and the standard deviations, respectively, of independent triplicates. Means with the same letter are statistically identical (one way ANOVA followed by Tukey test, $p<0.05)$.

difference in resisting PCO in mid-log and stationary phase but higher resistance in late-log phase.

\subsection{Factors accounting different bacterial sensitivity towards PCO inactivation}

\subsubsection{Superoxide dismutase and catalase levels in stationary phase}

Table 2 shows the relationship between SOD and CAT levels and the corresponding susceptibility towards PCO among the bacteria in their stationary phase. SOD levels were measured to be 2.03 and $0.81 \mathrm{U} / \mathrm{mL}$ for P. phosphoreum and A. alvinellae, respectively, while their corresponding CAT levels were 0.48 and $0.13 \mathrm{U} / \mathrm{mL}$. It was noted that $P$. phosphoreum, bearing a higher SOD and CAT level, was more resistant towards PCO inactivation than A. alvinellae.

Table 1 - Inactivation efficiency of PCO towards

A. alvinellae and P. phosphoreum under three growth stages (mid-log, late-log and stationary phase)

\begin{tabular}{lccc} 
Bacteria & Mid-log & Late-log & Stationary \\
\hline A. alvinellae & $7.5-\log$ & $4.5-\log$ & 7.5-log \\
P. phosphoreum & $3.5-\log$ & 3.5-log & 4-log \\
\hline \multicolumn{2}{l}{ Standard deviation: $<0.5$ for all data. } \\
\hline
\end{tabular}


Table 2 - Relationship between bacterial susceptibility towards PCO and SOD/CAT level

\begin{tabular}{lccc} 
Bacteria & PCO susceptibility & $\begin{array}{c}\text { SOD level } \\
(\mathrm{U} / \mathrm{mL})\end{array}$ & $\begin{array}{c}\text { CAT level } \\
(\mathrm{U} / \mathrm{mL})\end{array}$ \\
\hline P. phosphoreum & 4-log inactivation & 2.03 & 0.48 \\
A. alvinellae & 7.5-log inactivation & 0.81 & 0.13 \\
\hline \multicolumn{5}{l}{ Standard deviation: $<0.5$ for all data. } \\
\hline
\end{tabular}

\subsubsection{Investigation on the superoxide dismutase and} catalase level induction by PCO

Apart from studying SOD and CAT levels in bacteria in their stationary phase, SOD/CAT induction among the two marine bacteria was investigated during a $45 \mathrm{~min}$ PCO reaction period (Fig. 4). Both bacteria showed an increase in SOD levels throughout the 45 min PCO disinfection, and P. phosphoreum demonstrated a greater inducible SOD content (15-fold increase) than A. alvinellae (8-fold increase). For the CAT levels, A. alvinellae demonstrated an inducible effect during the 45 min PCO reaction (6-fold increase). Although P. phosphoreum also exhibited this within the first $30 \mathrm{~min}$ (1.5-fold increase), the effect dropped soon afterward (0.4-fold decrease).

\subsubsection{Fatty acid (FA) analysis}

The chromatograms obtained from GC-FID showed that the two marine bacteria had 6 common fatty acids conserved in the membrane and cell wall structure, which were

i) saturated 12 carbon straight chain fatty acid (lauric acid);

ii) saturated 14-carbon straight chain fatty acid (myristic acid);

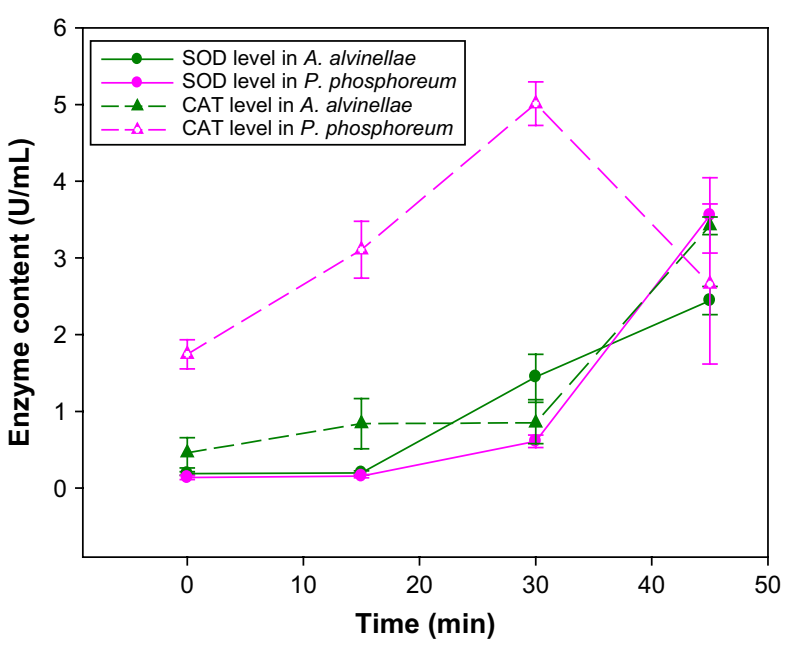

Fig. 4 - Induction of SOD and CAT levels under PCO disinfection of $A$. alvinellae and $P$. phosphoreum. Experimental conditions: $\mathrm{TiO}_{2}$ concentration $=100 \mathrm{mg} / \mathrm{L}$, light source (intensity) = fluorescent lamp (visible light intensity $=5.295 \mathrm{~mW} / \mathrm{cm}^{2}$ ), irradiation time $=45 \mathrm{~min}$, agitation rate $=200 \mathrm{rpm}$, initial cell density $=3 \times 10^{7} \mathrm{cfu} /$ $\mathrm{mL}$. Each data point and error bar represents means and the standard deviations, respectively, of independent triplicates. iii) saturated 16-carbon straight chain fatty acid (palmitic acid);

iv) unsaturated 16-carbon straight chain fatty acid with hydroxyl group (3-hydroxyl palmitic acid);

v) unsaturated 18-carbon straight chain fatty acid with 3 double bonds ( $\gamma$-linolenic acid);

vi) unsaturated 18-carbon straight chain fatty acid (oleic acid)

It was also noted that $P$. phosphoreum possessed a relatively higher ratio of unsaturated to saturated FA than A. alvinellae. On the other hand, P. phosphoreum had a comparatively lower ratio of branched to straight chain FA and short to long acyl chain FA than A. alvinellae (Table 3).

\subsection{The inactivation mechanism(s) of domestic light-driven photocatalysis}

\subsubsection{Leakage of potassium ion $\left(\mathrm{K}^{+}\right)$}

To determine the change in cell permeability, the leakage of $\mathrm{K}^{+}$was examined, as shown in Fig. 5(a), under the PCO treatment mediated by domestic lighting. It was observed that P. phosphoreum and A. alvinellae had an immediate increase of $\mathrm{K}^{+}$leakage, although at different levels, during the reaction. The resulting $\mathrm{K}^{+}$concentration, which was higher than that of the control with the presence of $\mathrm{TiO}_{2}$ in the dark (dark control), was remarkably parallel to the loss of cell viability (Fig. 5(b)). A. alvinellae, showing the greater leakage of $\mathrm{K}^{+}$(net leakage of $1.5 \mathrm{mg} / \mathrm{L} \mathrm{K}^{+}$), demonstrated a greater abatement rate from PCO treatment (3-log net inactivation). The slight increase of $\mathrm{K}^{+}$from the control resulted from a portion of cell undergoing natural die-off process.

\subsubsection{Total organic carbon analysis}

Total organic carbon analysis on PCO disinfection of P. phosphoreum was conducted (Fig. 6(ai) to 6(bii)). In solid phase analysis, TOC content continually dropped from $1.08 \mathrm{mg}$

Table 3 - Ratio of unsaturated to saturated FA

(UFAs:SFAs); ratio of branched to unbranched FA

(BCFAs:SCFAs) and ratio of short to long acyl chain FA

(SACFAs:LACFAs), and the percentage of three fatty acids

together with the corresponding inactivation efficiency

towards the two marine bacteria. Short chain fatty acids

were defined as any FA having containing less than 15

carbon atoms

\begin{tabular}{lcc} 
Bacterial strains & A. alvinellae & P. phosphoreum \\
\hline $\begin{array}{l}\text { Inactivation efficiency } \\
\quad \text { (log inactivation) }\end{array}$ & 7.5 & 4 \\
Ratio & & \\
UFA/SFA & 1.312 & 2.167 \\
BCFAs:SCFAs & 0.089 & 0.059 \\
SACFAs:LACFAs & 0.186 & 0.101 \\
Fatty acid (\% of total fatty acid) & & \\
Lauric acid, 12:0 & 3.04 & 0.61 \\
Myristic acid, 14:0 & 3.18 & 2.77 \\
Gamma-linolenic acid, & 1.91 & 0.59 \\
$\quad$ 18:3 w6c (6, 9, 12) & & \\
\hline Standard deviation: $<0.5$ for all data. & \\
\hline
\end{tabular}




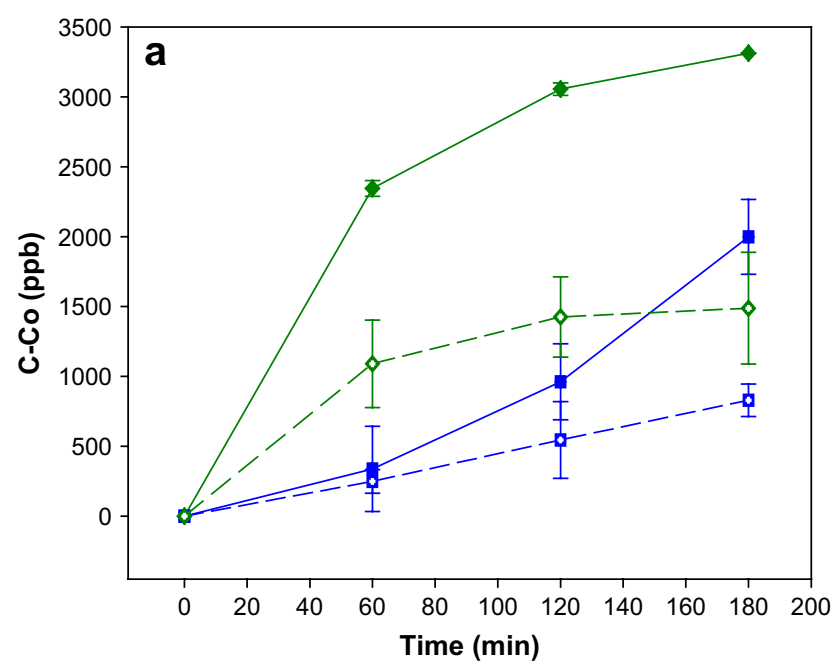

$\longrightarrow$ P. phosphoreum (PCO) - - P. phosphoreum (Dark control) $\longrightarrow$ A. alvinellae (PCO) $\quad-\diamond-$ A. alvinellae (Dark control)

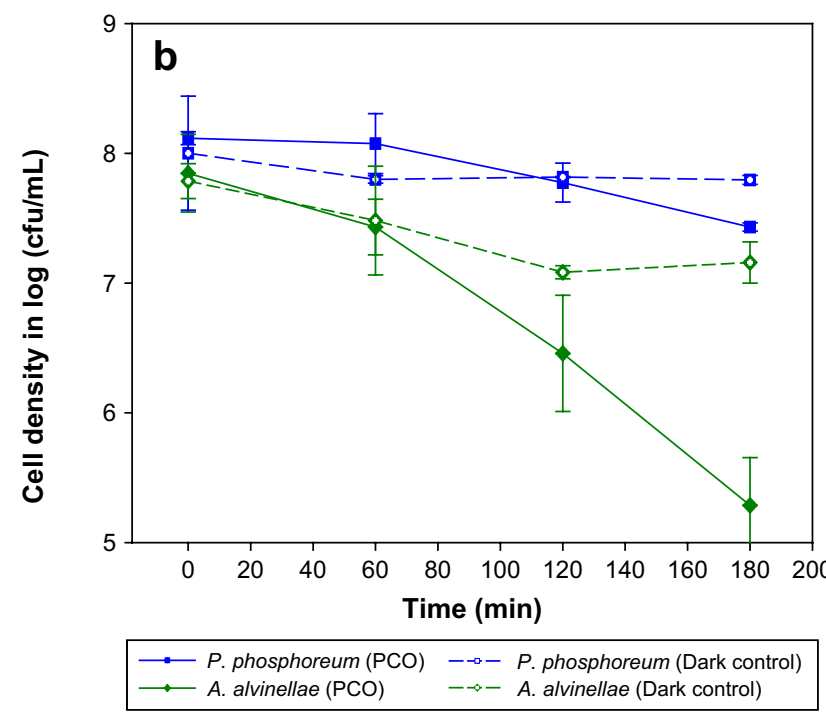

Fig. 5 - (a) Leakage of $\mathrm{K}^{+}$and (b) disinfection efficiency of PCO among the two marine bacteria. Experimental conditions: $\mathrm{TiO}_{2}$ concentration $=100 \mathrm{mg} / \mathrm{L}$, light source (intensity) = fluorescent lamp (visible light intensity $=5.295 \mathrm{~mW} / \mathrm{cm}^{2}$ ), initial cell density $=3 \times 10^{8} \mathrm{cfu} / \mathrm{mL}$. Each data point and error bar represents the mean and the standard deviations, respectively, of independent triplicates.

(9.23\% dry weight of cells) to $0 \mathrm{mg}$ during the $120 \mathrm{~h}$ PCO period. However, for liquid phase analysis, the time to reach zero TOC was much longer. TOC continued to increase during the reaction from $\mathrm{T}=0$ to $\mathrm{T}=120 \mathrm{~h}$, and then gradually dropped to the initial reading at $525 \mathrm{~h}(\sim 21$ days).

\subsubsection{Regrowth ability test}

It was observed that A. alvinellae and P. phosphoreum reached complete inactivation after a $10 \mathrm{~h}$ PCO reaction period. After the corresponding PCO treatments and the $96 \mathrm{~h}$ incubation period, the colony count (in $\mathrm{cfu} / \mathrm{mL}$ ) was below the detection limit.
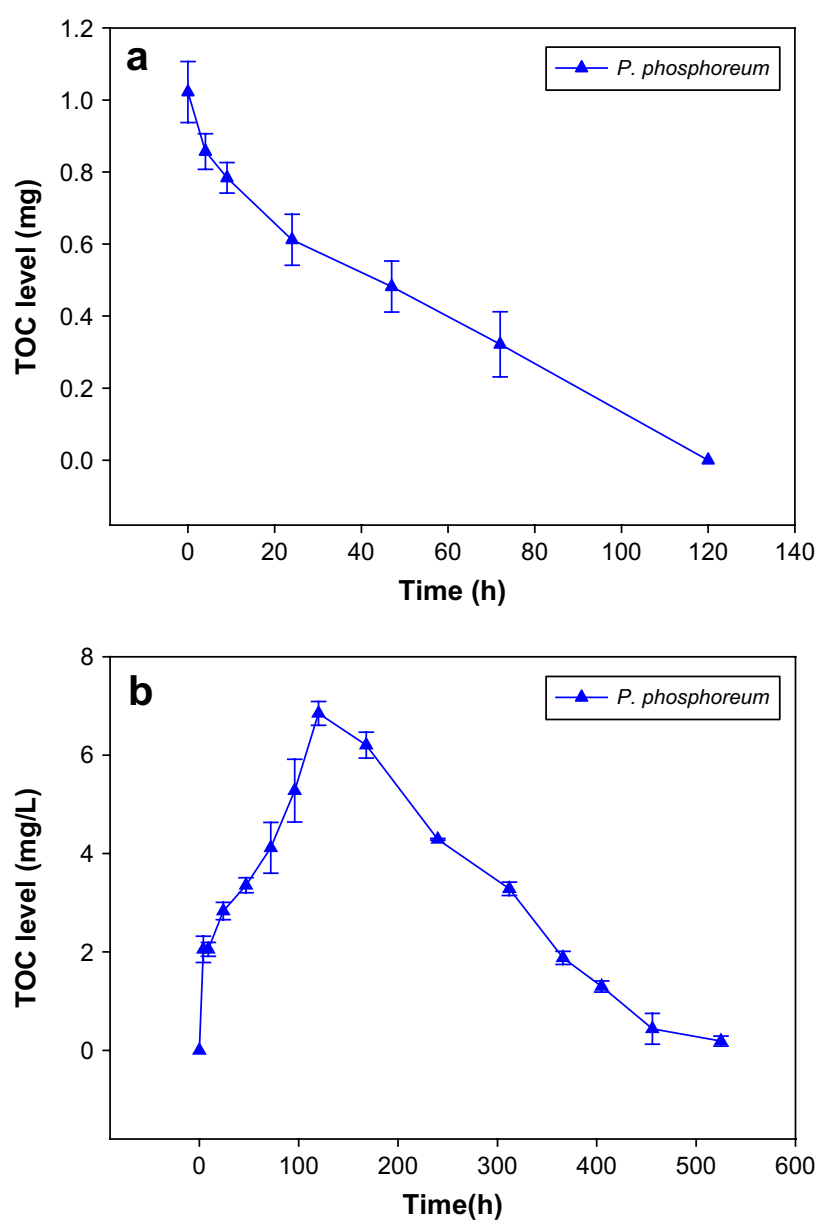

Fig. 6 - The total organic carbon (TOC, TOC $=$ total carbon (TC) - inorganic carbon (IC)) content of P. phosphoreum under (a) solid phase (solid organic carbon, SOC) and (b) liquid phase (dissolved organic carbon, DOC) TOC measurement during PCO treatment. Experimental conditions: $\mathrm{TiO}_{2}$ concentration $=100 \mathrm{mg} / \mathrm{L}$, light source (intensity) = fluorescent lamp (visible light intensity $=5.295 \mathrm{~mW} / \mathrm{cm}^{2}$ ), initial cell density $=3 \times 10^{8} \mathrm{cfu} / \mathrm{mL}$. Each data point and error bar represents the mean and the standard deviations, respectively, of independent replicates.

\section{Discussions}

\subsection{PCO efficiency using different light sources}

When comparing the two light sources, using fluorescent light as an alternative light source yielded a lower abatement rate for bacterial inactivation than UV-A irradiation. This result is reasonable since the UV-A intensity for UV-A lamp is 22 times higher than that of fluorescent light. By extending the irradiation time of fluorescent light to $180 \mathrm{~min}$, similar bacterial inactivation was achieved, indicating that the amount of UV-A irradiation emitted from the florescent light is sufficient to excite the $\mathrm{TiO}_{2}$ to generate enough $\cdot \mathrm{OH}$ for attacking microbial cells. Given that using fluorescent light would be safer, more 
environmental-friendly, practical and commonly available, it demonstrates the feasibility and applicability of this household light source for water disinfection. However, experimental conditions should be further optimized to maximize its disinfection efficacy.

\subsection{Effect of initial $p H$, temperature and growth phases}

Results reflected that acidic pH enhanced PCO disinfection efficiency for P. phosphoreum. There are several reasons for this phenomenon. First, as suggested by Cho et al. (2004), the isoelectric point of that photocatalyst $\mathrm{TiO}_{2}$ is approximately 6.3. When the environment $\mathrm{pH}$ is $<6.3$, the net surface charge of $\mathrm{TiO}_{2}$ becomes positive. Bacterial surfaces are in general negatively charged because negatively charged groups like carboxylates, polysaccharides and phosphonates usually predominate the positively charged groups like amides, peptides and proteins (Gumy et al., 2006). Based on this electrostatistic ground, at a $\mathrm{pH}$ reading of 5, the electrostatic attraction between the negatively charged bacteria and positively charged $\mathrm{TiO}_{2}$ will be stronger, providing a stronger affinity for the photocatalyst to adsorb on the bacteria surface. As a result, the contact surface area for $\cdot \mathrm{OH}$ to attack the bacteria increases, leading to an enhancement of bacterial inactivation. A second reason for the enhanced disinfection efficiency with a more acidic $\mathrm{pH}$ is because the $\mathrm{pH}$ would also affect the rate of PCO reaction. According to Legrini et al. (1993), the concentration of hydroxyl radicals $(\cdot \mathrm{OH})$ increases with the concentration of hydrogen ions $\left(\mathrm{H}^{+}\right)$. The overall photo-reaction can be described by following equations

$\mathrm{OH}^{-}+2 \mathrm{H}^{+}+\mathrm{O}_{2}^{-} \stackrel{\mathrm{TiO}_{2}}{\rightarrow} 3 \cdot \mathrm{OH}$

$[\cdot \mathrm{OH}]^{3}=\mathrm{K}_{e} \mathrm{~K}_{w}\left[\mathrm{H}^{+}\right]\left[\mathrm{O}_{2}^{-}\right]$

Different bacterial species would have their own structural components, e.g. cell wall structure, which would dictate the bacterial surface charge against PCO reaction. From the results, A. alvinellae showed no change in disinfection efficiency when $\mathrm{pH}$ ranged from 5 to 8 . One of the possible reasons may be because the role of the electrostatic interaction between the cell surface and $\mathrm{TiO}_{2}$ surface was less significant in determining the overall photocatalytic activity owing to the weak adsorption affinity or the relatively neutrally charged bacterial surface.

According to Rincón and Pulgarin (2003), it was suggested that there was a positive effect of heating on photocatalytic inactivation of Gram-negative coliforms. In addition, similar results were found in Cho et al. (2004), showing a faster inactivation rate of $E$. coli at higher temperatures. It is well known that photochemical reactions are temperature independent, thus higher temperature would not improve the generation of $\bullet \mathrm{OH}$; instead, it would change the morphological and physiological state of bacteria, which boosts the microbial susceptibility towards PCO attack (Cho et al., 2004). Furthermore, higher temperature would increase membrane fluidity, thus enhancing the permeability of ROS into intracellular compartments, which in turn would augment disinfection efficiency (Aricha et al., 2004). Microorganisms in marine habitats commonly possess a psychrotolerant property (Flodgaard et al., 2004), enabling them to better adapt and resist colder environments. Moreover, they are used to adapting to more stable and low temperature water habitats. Therefore, increasing temperature, e.g. to $37^{\circ} \mathrm{C}$, would enhance their sensitivity to oxidative attack, resulting in a greater inactivation rate.

Numerous reports have been focused on the effect of growth phases towards bacterial susceptibility under different stress conditions. However, the results were conflicting and no general conclusion has yet been found. Some findings suggested higher bacterial susceptibility towards stress conditions such as pressure and hyperosmolarity, which was discovered in exponential phase (Pagán and Mackey, 2000; Jydegaard et al., 2000). Other reports revealed similar sensitivity in stationary and log-phased cells (Komerik and Wilson, 2002), while Keller and Maxcy (1984) observed diverse patterns of survival response to UV irradiation under different growth phases in different bacteria.

In this study, bacteria of different growth stages illustrated diverse survival responses under oxidative stress conditions. In different growth stages, a specific stress-resistant gene would be expressed at different phases and extents (Rincón and Pulgarin, 2004). For instance, rpoS (katF) sigma factor, a stationary phase-induced gene conferring on Salmonella typhimurium and E. coli, was responsible for its marked resistance to stress conditions, e.g. oxidation, heat shock, etc. (Munro et al., 1995). Moreover, the survival response in different phases was influenced by various factors, such as the population involved to repair damaged DNA, the adequacy of nutrients, the change in cellular properties or enzymatic activity (e.g. repair enzymes for DNA repair) (Morton and Haynes, 1969). The proportion, distribution and combination of all these features would be varied under different growth stages, and thus contribute to its diverse pattern of inactivation response among studied bacteria.

From the results, one can assume that aside from temperature, both $\mathrm{pH}$ and bacterial growth stages also affect the efficiency of photocatalytic treatment. In a real application, a pool of assorted bacteria with different growth phases would exist in seawater, a more technical and integrated PCO system with optimal operation time, dose of irradiation and quantity of photocatalyst was crucial to ascertain the efficacy of the bacterial inactivation by PCO process.

\subsection{Catalase and superoxide dismutase activity}

To investigate the possible reasons for different bacterial sensitivity towards PCO reaction, two intracellular enzymes, known as catalase (CAT) and superoxide dismutase (SOD) were studied among two selected bacteria. CAT is an antioxidant enzyme catalyzing the decomposition of hydrogen peroxide to water and oxygen, while SOD is a metalloenzyme catalyzing the dismutation of superoxide radicals into hydrogen peroxide and oxygen. They are the common enzymes responsible for defending oxidative stress from the environment. Since SOD and CAT are enzymes protecting bacteria from oxidative stress, higher SOD and CAT levels implied bacteria can defend against $\cdot \mathrm{OH}$ attack from PCO to a greater extent. 
Our results supported the assumption that SOD and CAT would exert their antioxidative roles while the PCO reaction took place. During the PCO process, reactive oxygen species (ROS) such as superoxide would generate hydrogen peroxide by the action of superoxide dismutase. Bacteria possessing these two enzymes would be capable of scavenging ROS into harmless substances or hinder the production of $\bullet \mathrm{OH}$, thus attenuating the oxidative attack from PCO.

Results regarding the SOD and CAT induction revealed that these two antioxidative enzymes would become inducible under PCO in an attempt to defend themselves from photocatalytic attack of $\cdot \mathrm{OH}$. However, the amount induced is not strongly correlated with the bacterial sensitivity towards PCO, the induction of both enzymes in A. alvinellae is higher, yet it got $\sim 1.5$-log inactivation compare with $\sim 0.75-\log$ inactivation of $P$. phosphoreum (Fig. 1). One of the possible reasons would be due to the species susceptibility towards PCO rather depend on the intrinsic antioxidative enzymes (Table 2), and the level of induction may only play minor role for compromising the oxidative stress. Besides, other factors also affect the bacterial susceptibility towards PCO. For instance, there were other enzymes such as glutathione, peroxidase, caroteniod, etc. involved in defending the oxidative stress from environment. Moreover, different bacteria might have different structural configurations, e.g. fluidity in the cell wall or cell membrane, which might affect its susceptibility towards the attack of ROS. Further investigation was needed to identify their roles in PCO process. PCO disinfection would be attributed to 1) a net devastating effect on induced CAT by oxidative attack, and 2) oxidative damage on enzymatic function overwhelming the production of CAT.

\subsection{Fatty acid profile}

Fatty acids in bacteria were mainly found in cytoplasmic and outer membrane of the cell. It is generally reported that the change in lipid composition by the adjustment of fatty acid arrangement enables microorganisms to overcome the environmental fluctuation (Guerzoni et al., 2001).

In our previous report, Cheng et al. (2007) suggested that unsaturated fatty acids are more prone to peroxidation than saturated fatty acids. Other than decreasing the desaturation level of fatty acids, increasing the branching and shortening the acyl chain length of fatty acid could prevent the penetration of undesirable molecules, e.g. ROS, providing the resistance to oxidative stress (Guerzoni et al., 2001; Aricha et al., 2004). Our results demonstrated the combined effect of these three factors, the more PCO-resistant species P. phosphoreum, despite having greater ratio of unsaturation level. It contained a smaller ratio of branching and short chain FA, which contributed to the tightly packed lipid arrangement in membrane. While for the more PCO-sensitive species like A. alvinellae, apart from having relatively less proportion of branched and short chain FA, it also had a relatively large proportion of unsaturated fatty acid, which contributes its sensitivity to PCO. This indicated that the proportion of unsaturated FA, the length of FA and the branching of FA would all exert their roles to defend against PCO attack.

\subsection{Measurement of $\mathrm{K}^{+}$leakage from inactivated bacteria}

Virtually, $\mathrm{K}^{+}$exists in bacteria and is involved in the regulation of polysome content and protein synthesis (Hu et al., 2006). It was clearly noted that any damage in the membrane structure would result in the leakage of $\mathrm{K}^{+}$; thus, resulting in cell dysfunction or death. This is because PCO oxidized the cell and membrane by lipid peroxidation (Saito et al., 1992). During the PCO process, highly reactive oxidative species (ROS) such as $\cdot \mathrm{OH}$ and $\cdot \mathrm{O}_{2}^{-}$would be generated and directly attack the outer and cytoplasmic membrane, leading to the leakage of intracellular material, e.g. $\mathrm{K}^{+}$. Consequently, bacterial cells would suffer from inactivation or even death. Further investigation would be carried out to explore the detailed inactivation mechanism by transmission electron microscopy (TEM).

\subsection{Investigation of cell mineralization by total organic carbon analysis}

As initially reported by Jacoby et al. (1998), complete oxidation of organic matter, in bacterial cells, into carbon dioxide could be achieved by photocatalysis. To quantitatively study the level of bacterial mineralization by PCO, total organic carbon (TOC) analysis on P. phosphoreum was carried out. Complete removal of the TOC under solid phase measurements proved that PCO disinfection could lead to complete oxidation of organic matter in marine bacterial cells. In aqueous-phase TOC analysis, the initial surge of the TOC level was mainly due to the partial oxidation of large organic molecules into smaller dissolved organic carbon (DOC), while the TOC eventually dropped to zero due to the complete mineralization of all organic matter including DOC into carbon dioxide that released from the reaction mixture.

Moreover, the time needed for total bacterial mineralization was much longer than that for complete inactivation by PCO. Though cell viability was entirely lost by the attack of $\cdot \mathrm{OH}$, organic matter inside the bacteria was not completely mineralized at the same time. In addition, the presence of recalcitrant organic compounds in the mixture would also prolong the time to reach complete removal of organic matter (Cheng et al., 2007).

Bacterial mineralization is a vital index indicating the selfcleaning efficiency for water disinfection. From the results obtained, PCO disinfection driven by domestic lighting and presence of $\mathrm{TiO}_{2}$ possessed the self-cleaning property. Though it required a long time to achieve complete mineralization of the organic compounds, it was a clean and safe process as it did not require extra steps to separate the inactivated cell debris from the treated water.

\subsection{Regrowth ability test}

In this experiment, a regrowth test was conducted to evaluate the effectiveness of bacterial disinfection by the PCO process. Following a $96 \mathrm{~h}$ recovery period, an undetectable bacterial count for the selected bacterial strains revealed that photocatalytic disinfection had led to irreversible damage to the bacteria or brought the damaged bacteria to a state of "viable but non-culturable" state (VBNC), which meant bacteria were 
unable to return to the culturable state unless favorable conditions were provided (Dunlop et al., 2002).

\section{Conclusions}

Photocatalytic disinfection of marine bacteria using fluorescence light was found to be feasible and effective. The fluorescent light photocatalytic disinfection is more safe and cost effective as compared to disinfection using UV and chlorine since the latter ones use hazardous irradiation and produce disinfection byproducts, respectively, in the process. The regrowth experiment indicates that the photocatalytic disinfection completely inhibits the regrowth of the bacteria, which is superior than the disinfection methods commonly used.

The susceptibility of bacteria to photocatalytic disinfection in different growth phases was found to be species-specific, for instance, $P$. phosphoreum has similar response in different growth phases while A. alvinellae in late-log phase is more resistant. In addition, bacterial strains have different activities of SOD and CAT - the two antioxidative stress enzymes and different ratios of unsaturated fatty acid to saturated fatty acid show different susceptibilities to photocatalytic disinfection. It will be interesting to study any correlation between the susceptibility to photocatalytic disinfection and the levels of SOD and CAT, or the ratios of unsaturated fatty acid to saturated fatty acid in different growth phases of the two bacteria used in this study.

\section{Acknowledgments}

The project was supported by a research grant (CUHK4585/06 M) of Research Grant Council, Hong Kong SAR Government, allocated to P.K. Wong, C.Y. Chan, C. Hu and J.C. Yu. The authors would like to thank the critical review and suggestions of Dr. K.H. Wong.

\section{R E F E R E N C E S}

Aricha, B., Fishov, I., Cohen, Z., Sikron, N., Pesakhow, S., KhozinGoldberg, I., Dagan, R., Porat, N., 2004. Differences in membrane fluidity and fatty acid composition between phenotypic variants of Streptococcus pneumoniae. Journal of Bacteriology 186, 4638-4644.

Cell Technology, 2006. Protocol for Superoxide Dismutase Assay and Catalase Assay. Mountain View, CA, USA.

Cheng, Y.W., Chan, C.Y., Wong, P.K., 2007. Disinfection of Legionella pneumophila by photocatalytic oxidation. Water Research 41, 842-852.

Cho, M., Chung, H., Choi, W., Yoon, J., 2004. Linear correlation between inactivation of $\mathrm{E}$. coli and $\mathrm{OH}$ radical concentration in $\mathrm{TiO}_{2}$ photocatalytic disinfection. Water Research 38, 1069-1077.

Dunlop, P.S.M., Byrne, J.A., Manga, N., Eggins, B.R., 2002. The photocatalytic removal of bacterial pollutants from drinking water. Journal of Photochemistry and Photobiology A: Chemistry 148, 355-363.

Farr, S.B., Kogoma, T., 1991. Oxidative stress responses in Escherichia coli and Salmonella typhimurium. Microbiology Reviews 55, 561-585.
Flodgaard, L.R., Dalgarrd, P., Andersen, J.B., Nielsen, K.F., Givskov, M., Gram, L., 2004. Nonbioluminescent strains of Photobacterium phosphoreum produce the cell-to-cell communication signal $\mathrm{N}$-(3-hydroxyoctanoyl) homoserine lactone. Applied and Environmental Microbiology 71, 2113-2120.

Guerzoni, M.E., Lanciotti, R., Cocconcelli, S., 2001. Alteration in cellular fatty acid composition as a response to salt, acid, oxidative and thermal stresses in Lactobacillus helveticus. Microbiology 147, 2255-2264.

Gumy, D., Morais, C., Bowen, P., Pulgarin, C., Giraldo, S., Hajdu, R., Kiwi, J., 2006. Catalytic activity of commercial of $\mathrm{TiO}_{2}$ powders for the abatement of the bacteria (E. coli) under solar simulated light: influence of the isoelectric point. Applied Catalysis B: Environmental 63, 76-84.

$\mathrm{Hu}, \mathrm{X}$., Hu, C., Qu, J.H., 2006. Photocatalytic decomposition of acetaldehyde and Escherichia coli using NiO/SrBi2O4 under visible light irradiation. Applied Catalysis B: Environmental 69, 18-24.

Jacoby, W.A., Maness, P.C., Wolfrum, E.J., Blake, D.M., Fennel, J.A., 1998. Mineralization of bacterial cell mass on a photocatalytic surface in air. Environmental Science and Technology 32, 2650-2653.

Jydegaard, A.M., Gravesen, A., Knøchei, S., 2000. Growth condition-related response of Listeria monocytogenes 412 to bacteriocin inactivation. Letters in Applied Microbiology 31, 68-72.

Keller, L.C., Maxcy, R.B., 1984. Effect of physiological age on radiation resistance of some bacteria that are highly radiation resistant. Applied and Environmental Microbiology 47, 915-918.

Komerik, N., Wilson, M., 2002. Factors influencing the susceptibility of Gram-negative bacteria to toluidine blue O-mediated lethal photosensitization. Journal of Applied Microbiology 92, 618-623.

Legrini, O., Oliveros, E., Braun, A.M., 1993. Photochemical process for water treatment. Chemistry Reviews 93, 671-698.

Maness, P.C., Smolinski, S., Blake, D.M., Huang, Z., Wolfrum, E.J., Jacoby, W.A., 1999. Bactericidal activity of photocatalytic $\mathrm{TiO}_{2}$ reaction: toward an understanding of its killing mechanism. Applied and Environmental Microbiology 65, 4094-4098.

Matsunaga, T., Tomoda, R., Nakajima, T., Nakajima, N., Komine, T., 1988. Continuous sterilization system that uses photosemiconductor powders. Applied and Environmental Microbiology 54, 1330-1333.

Morton, R.A., Haynes, R.H., 1969. Changes in the ultraviolet sensitivity of Escherichia coli during growth in batch cultures. Journal of Bacteriology 97, 1379-1385.

Munro, P.M., Flatau, G.N., Clement, R.L., Gauthier, M.J., 1995. Influence of the RpoS (KatF) sigma factor on maintenance of viability and culturability of Escherichia coli and Salmonella typhimurium in seawater. Applied and Environmental Microbiology 61, 1853-1858.

Pagán, R., Mackey, B., 2000. Relationship between membrane damage and cell death in pressure-treated Escherichia coli cells: differences between exponential and stationary-phase cells and variation among strains. Applied and Environmental Microbiology 66, 2829-2834.

Pal, A., Pehkonen, S.O., Yu, L.E., Ray, M.B., 2007. Photocatalytic inactivation of Gram-positive and Gram-negative bacteria using fluorescent light. Journal of Photochemistry and Photobiology A: Chemistry 186, 335-341.

Rincón, A.G., Pulgarin, C., 2004. Bactericidal action of illuminated $\mathrm{TiO}_{2}$ on pure Escherichia coli and natural bacterial consortia: post irradiation events in the dark and assessment of the effective disinfection time. Applied Catalysis B: Environmental 49, 99-112. 
Rincón, A.G., Pulgarin, C., 2003. Photocatalytic inactivation of E. coli: effect of (continuous-intermittent) light intensity and of (suspended-fixed) $\mathrm{TiO}_{2}$ concentration. Applied Catalysis B: Environmental 44, 263-284.

Saito, T., Iwase, T., Horie, J., Morioka, T., 1992. Mode of photocatalytic bactericidal action of powdered semiconductor
$\mathrm{TiO}_{2}$ on mutans streptococci. Journal of Photochemistry and Photobiology B: Biology 14, 369-379.

Shimadzu Corporation, 2001. Total Organic Carbon Analyzer (TOC-V $\mathrm{V}_{\mathrm{CSH} / \mathrm{CSN}}$ ) - User Manual, Kyoto, Japan.

World Health Organization, 2004. Guidelines for Drinking-Water Quality: Microbial Aspect. World Health Organization, 24 pp. 